Postprint de: Ferreri, M. And Dawson, G. Self-precarization and the spatial imaginaries of property guardianship, entregada a: cultural geographies.

The final version is available at: https://doi.org/10.1177/1474474017724479

\title{
Self-precarization and the spatial imaginaries of property guardianship
}

Property guardianship, a form of short-term building security through temporary dwelling, has emerged in several European countries over the last twenty years. Despite being characterised by tenure insecurity and often substandard conditions, 'living as a guardian' has become a composite and polyvalent mode of inhabiting cities, rooted in the production and dissemination of distinctive spatial imaginaries of 'nomadic' urban dwelling. In the United Kingdom, where guardianship is relatively novel and marginal, the establishment of several intermediary companies has contributed to the rapid diffusion of the scheme as precarious 'adventurous' housing, particularly in metropolitan areas where guardianship schemes largely attract mobile and universityeducated individuals. Drawing on debates about the complexities of 'self-precarization' (Lorey, 2006), this article examines imaginaries of property guardianship and their ambivalent significance in relation to lived processes of precarization. Through the analysis of media representations and in-depth interviews with current and former guardians in London, it explores how guardians mobilise narratives of adaptability, flexibility and nomadism, between resignation to existing housing conditions and a sense of critical and autonomous agency. The article proposes and develops a nuanced qualitative approach to analyse how precarious dwelling through guardianship is reshaping spatial imaginaries of acceptable and desirable urban dwelling, and contributing to significant processes of individual and collective subjectification. At a moment of extensive governmentality through insecurity, it concludes that examining imaginaries and practices of self-precarization offers a critical entry point for understanding and rethinking, theoretically and politically, housing precarity and its geographies.

Keywords: property guardianship, precarization, subjectivity, precarious geographies, alternative housing

\section{Introduction}

I have basically lived with Camelot since I have been in London, pretty much, and that's four years. I have been in four properties and then in several locations in between while waiting for another property. And I have got a real strong lovehate relationship [toward it] ...and it really is polarised like that. An absolute 
adoration, and a kind of lifeline, kind of attitude to them, and then, absolute resentment and horrific kind of intolerance [...] so this is why I wanted to talk to you because there can be a lot of people with misconceptions about what it is, and what it means, and what the bad points are and what the good points are. ${ }^{1}$

Since the 1990s, starting in the Netherlands and spreading across Europe, companies have been founded to manage vacant buildings through schemes called 'property guardianship' (PG). Guardianship companies can be best understood as intermediary agencies that provide low-cost or cost-free property security by installing live-in 'guardians' on temporary licenses. The Dutch company Camelot Property Management, mentioned in the quotation above, is the largest of a 'growing niche'2 of over thirty-three companies registered in the United Kingdom, of which at least twentytwo have been founded since the global financial crisis of $2008 .^{3}$ Guardians, for their part, pay a monthly live-in 'license fee' that is usually lower than monthly rent in the private rented sector, in order to access sites that tend to be larger and more centrallylocated than those available on an equivalent budget. Limited studies to date show that PG schemes in urban areas attract largely university-educated individuals with high social and cultural, but not necessarily economic, capital ${ }^{4}$, and are particularly economically advantageous for those in precarious and low-paid employment. The main drawback of the scheme is its reliance on live-in licenses which can be terminated at two weeks' notice, making guardianship a largely rights-free tenure and one of the most precarious (legal) forms of residential dwelling in the UK. ${ }^{5}$

The rise of guardianship in the UK, and particularly in London, over the last decade has been accompanied by the production and dissemination of distinctive spatial and cultural imaginaries. Not only it is presented as a 'win-win' ${ }^{6}$ solution to both property vacancy and the need for affordable housing, but it is also celebrated as 
offering a 'nomadic' way of living that resonates with imaginaries of 'lifestyle squatting, ${ }^{7}$ and with architectural and planning experiments questioning permanence and the fixity of function in favour of visions of the city based on mobile and flexible uses. ${ }^{8}$ Social and spatial imaginaries of flexibility and nomadism as dissident ${ }^{9}$ inform the polyvalence of guardianship, at a tension with its precarious conditions. This has important implications for lived experiences of guardianship, which can be characterised by a high degree of ambivalence and, as in the opening quotation, by a 'polarized love-hate' relationship with temporary dwellings, as well as with the precarious lives which this kind of housing both enables and requires.

The aim of this article is to examine the polyvalence of PG, and the development of its public representations in the UK, and its relationship with the often ambivalent narratives of guardians, explored through in-depth interviews, which express resignation as well as politically significant critiques of existing imaginaries and practices of urban dwelling. In order to critically address the latter, we draw on theorist Isabell Lorey's concept of 'self-precarization' to argue that guardians' precarity cannot simply be theorized as a condition of oppression, but needs instead to be understood as part of wider processes of individual and collective subjectification under conditions of normalised precarization. With this, we aim to offer a grounded contribution to debates about imaginaries and practices of urban flexibility and mobilities ${ }^{10}$ and about precarious geographies, particularly in relation to housing. Approaching both lived and imagined geographies allows us to attend to the ways in which practices such as PG are reshaping not just the boundaries of what constitutes acceptable, and even desirable, urban living, but also the processes of subject formation at times of widespread housing and life insecurity. 


\section{Property Guardianship: between squatting and anti-squatting}

The rise of property guardianship as a form of precarious urban dwelling has been a relatively understudied issue. Scholarship to date has focused on the legal dimensions of the scheme and the position of temporary licenses in the context of national housing legislation. ${ }^{11}$ While this approach is fundamental to contextualising PG within wider housing and urban dynamics, it does not adequately address the reasons why guardianship has rapidly become an appealing and desirable form of dwelling. A more nuanced understanding can be gained by attending to the imagined and lived geographies of PG, and its significance for debates in the burgeoning subfield of precarious geographies. To do so, in this first section we outline three elements of our conceptual framework. The first concerns the material and cultural roots of PG in squatting and anti-squatting, showing how forms of 'licensed living' have emerged as simultaneously a functional contrary and a cultural recoding of vacant space occupations. The second element relates to the complex question of self-precarization under conditions of widespread precarization. The third and last element in our approach concerns the role of temporariness and flexibility in imaginaries of urban spaces, and its ambiguous positioning as both desirable and threatening, received and produced.

To understand the material and cultural roots of urban 'licensed living', it is useful to revisit the origins of PG and its relationship to European urban squatting movements. In the Netherlands, its emergence was closely linked to changes in antisquatting legislation and housing policy. In response to the widespread squatting movement of the previous decade, the 1980s were marked by an anti-squatting counteroffensive centred on the management of vacant buildings. Property owners strategically offered short-term leases to students and artists in vacant spaces as 
deterrent to squatters, a practice called kraakwatch (squat watch) but often referred to by squatters as anti-kraak (anti-squat). ${ }^{12}$ At the time, the founding of the first PG agencies coincided with the passing of the Leedstandwet (the Vacant Property Act, 1987), which made squatting riskier and more difficult, marking the decline of the movement. ${ }^{13}$ During the 1990 s, in the context of widespread tenure fragmentation ${ }^{14}$, PG rapidly transformed from a marginal temporary security practice to one of many forms of insecure housing, alongside other temporary rental tenures. ${ }^{15}$

While the historical origins of PG are to be found in localized and national responses to the squatting movement, it is important to underline that PG companies were founded in answer to the 'threat' of squatting and vandalism of vacant properties, rather than of squatting per se. As observed by Hugo Priemus, the establishment of PG companies in the Netherlands occurred at a time when the squatting movement had already started to decline, and that 'the anti-squatters far outnumber the squatters at any time in their history ${ }^{\prime 6}$. The provision of kraakwatch (or anti-kraak) as a response to an imagined threat of unlawful occupation finds echoes in the English context, where the threat of squatting is often greatly exaggerated by PG companies ${ }^{17}$ when compared to even the most optimistic estimates. ${ }^{18}$ Nonetheless, the unusual locations and living conditions of guardians are so evocative of countercultural appropriations of vacant spaces that PG is known among guardians as well as in common parlance as 'licensed' or 'legal squatting', a composite idea that will be explored further in the article.

\section{Precarity and self-precarization}

The 'security' provided through PG schemes is predicated upon the guardians' own insecurity, mediated by profit-making intermediaries. Guardians' ability to move into a vacant building at short notice and on a temporary basis requires a degree of 
flexibility that can be seen as symptomatic of a more general precarity of labour and life, particularly in urban contexts. ${ }^{19}$ The concept of 'precarity' has been deployed in geographical debates to discuss, on the one hand, the interconnectedness of migrant status, labour and life at a time of large-scale migration and changing bordering and migration practices ${ }^{20}$, and on the other hand, to understand labour and life conditions experienced by workers in the service, creative and knowledge economy sectors. ${ }^{21}$ Arguments have been made to understand precarity as more than 'a position in the labour market' ${ }^{22}$, which should instead be theorised as simultaneously a subject position and its rationale and affective embodiment. ${ }^{23}$

Building on the work of Judith Butler ${ }^{24}$, theorist Isabell Lorey has proposed to distinguish between precariousness, precarity and precarization ${ }^{25}$ While precariousness is a shared condition of relationality, precarity is defined as a category of order, a classifying designation of the distribution of precariousness in hierarchies of inequality. ${ }^{26}$ Precarization, finally, is seen as the governing of subjects through insecurity and destabilization, and its accompanying subject formations. Her approach emphasises an understanding of precarization as an instrument of governing that 'embraces the whole existence, the body, modes of subjectification' ${ }^{27}$, which inadvanced capitalist countries, are characterized by an unresolved tension between subjection to normalized precarization and modes of empowered autonomy and liberation from the state and from market logics. Deploying a framework based on a critical furthering of Foucauldian theories of governmentality, Lorey discusses the internalisation of insecure conditions and its associated ideas of freedom and autonomy as a mode of 'self-precarization' ${ }^{28}$, defined as the techniques of self-governance of neoliberal 'flexible' subjects, understood not as those 'forced' into precarization but as 'those who have freely chosen precarious living conditions'. ${ }^{29}$ 
Under conditions of normalised precarization, modes of subjectification through 'self-precarization' can point towards conformist forms of management of the self, but also towards modes of acting that 'break through, refuse, or escape from appeals to functional self-government ${ }^{30}$ and that can be usefully explored to assess the potential for dissent and the production of alternatives. Being mindful of this duality requires approaching self-precarization not simply as a form of powerless subjection. While for some the rationale for becoming guardians and for engaging in temporary urban living is informed by resignation to dominant conditions, thus enabling 'extraordinary governability' ${ }^{31}$, for others it is informed by the appeal of alternative and more flexible ways of dwelling in and inhabiting the city.

\section{Flexible spaces and the 'No-Stop City'}

The urban cultural imaginary of 'flexibility' is key to definitions and selfdefinition of PG as a form of urban self-precarization. As explained by a current guardian, "the key to being a property guardian is flexibility in every respect". 'Flexibility' here is synonymous with resourcefulness and ability to adapt to changes in circumstance. As noted by cultural theorist Brian Holmes, the notion of 'flexibility' points both to job casualisation as well as to an 'entire set of very positive images, spontaneity, creativity, cooperativity, mobility, peer relations, appreciation of difference, openness to present experience, ${ }^{32}$. Ideas of self-organisation, nomadic workplaces and a blurring of life and work, characteristic of the European left's social critique in Fordist societies, have become central to contemporary work ideology The incorporation of 'flexible' work and life values into the reorganisation of mainstream management of firms and institutions has led Luc Boltanski and Eve Chiapello to argue for the emergence of a 'new spirit of capitalism' characterised by the emergence of a 
'projective' logic that comprises both forms of management and self-management of labour and sociability, and a discursive system in which deterritorialised and networked forms of acting are given meanings, values and justifications. ${ }^{33}$

The transposition of the values of flexibility and adaptability in spatial imaginaries and practices is visible in the critical urban and architectural practices that emerged in the 1960s and 1970s as intrinsic to a project of social and spatial transformation. One of the most critical example of these experimental architectural ideals was the 'No-Stop city' (1968-1972) bye Italian architecture collective 'Archizoom'. Similar to the 'plug-in city' of New Babylon (1956-1974) designed by artist and architect Constant ${ }^{34}$, in the No-Stop City 'humanity would live as nomads, moving around, setting up tents, plugging in at any location'. ${ }^{35}$ No-Stop City, interpreted as 'a cynical parody of the dreams of flexibility and choice in the architectural landscape ${ }^{36}$, was conceived as pushing architecture and the urban to 'an absolute limit', in which undistinguishable spaces, without detail and specific functions, would be completely re-adaptable, 'a city without architecture'.

The blueprint of the No-Stop City offers a reflection on a logic of interchangeable spaces in which urban dwellers reside without attachment to place and in which the very idea of a functionally-differentiated 'residential' space loses meaning. Non-stop mobility alongside notions of 'plug-in' and flexible architecture shape both a social and a spatial imaginary of nomadic urban inhabitation. Through PG, city living is re-imagined according to a strategy of non-stop on-demand occupations that embodies the dream of the absolute limit of detachment, nomadic lifestyles and placelessness. As will be explored in the following section, however, attending to the lived experiences of 'plugging in at any location' brings a powerful critical angle to 
those celebratory imaginaries, and their embeddedness in forms of representation and self-representation.

\section{Between representations and lived experiences}

Our study draws on a mixed-methods approach, encompassing thematic and discourse analysis of visual and textual representations by PG companies and by a range of national and local print media between 2012 and 2016, and in-depth semi-structured narrative interviews with twenty-nine current and former guardians living in Greater London through seven PG companies (2011-14). ${ }^{37}$ Interviews combined open-ended questions and discussions regarding the guardians' background, education, life and work. As suggested by other small-scale qualitative studies of PG in London ${ }^{38}$, the schemes largely attract highly mobile university-educated individuals, and particularly those working the 'creative' and not-for-profit sectors, characterized by flexibility and a high degree of precarity ${ }^{39}$, exacerbated by periods of unpaid or low-paid work. ${ }^{40}$

Participants in our study were all between 20 and 40 years of age, had been through tertiary education and were citizens of the UK or of other European Union countries. In terms of gender, the spread was relatively even. Most self-identified as middle-class and supported themselves through a mixture of part-time and freelance work, and a considerable number were pursuing higher education or training. While we focused on exploring the singularity of individual experiences, most of the participants commented that based on their own experience, in some case across several multioccupation buildings, the profile of our interviewees was fairly representative of guardians in London. ${ }^{41}$

Whenever possible, interviews took place in the guardianship properties themselves, in order to supplement guardians' narratives with observations of the sites 
and a more expanded sense of dwelling and embodiment, concepts which are central to feminist approaches to the 'home' as processual and as 'a vital space for understanding the micro-geographies of social and spatial uncertainty ${ }^{42}$. Research participants were initially approached through personal connections and snowballing; this strategy enabled both authors to gain access to a social group whose temporariness and lack of fixed sites made recruitment particularly difficult. The strategy enhanced the possibility of engaging in conversations that reflexively and critically explored the ambivalences and incoherencies in guardians' accounts. Moreover, a number of interviewees expressed a fear of being 'found out' by the companies and of having their license terminated; interpersonal connections and networks were mobilised to address concerns ahead of the interviews, guarantee anonymity and build trust.

\section{'Living in a castle'}

The following sections address the cultural geographies of property guardianship through a discussion of official and unofficial narratives and the production of positive imaginaries of self-precarization. Discourse analysis of PG companies' websites and media representations are combined with insights from interviews in order to discuss the appeal of living temporarily in a vacant property, and the attributes of precarity required and celebrated by such schemes as flexibility, a sense of adventure and resourcefulness.

Since the mid-2000s, Camelot and Ad Hoc, the two largest PG companies in Europe, have targeted local and national print and online media to promote guardianship, especially when the scheme was less well-known in the UK. The most prominent narratives deployed by PG companies and favourable media outlets rely on the appeal of the properties themselves. These include Grade II-listed mansions with 
annexed land, fire stations, lighthouses, theatres, Victorian hospitals and schools, former bathhouses, leisure and health centres, 'loft-style' warehouses, 1980s office buildings and high-rise modernist estates with vistas. In 2010 the popular British Look magazine ran a two-page report entitled 'We get to live in mansions for free - so can you!' The article portrays a smiling young nurse discussing her positive experience living as a Camelot guardian in a country estate and comparing it to the type of property she could afford in the private rental market, stressing the larger spaces and fairy-tale location. The caption plays with the projected fantasy of class promotion, showing that 'Kate loves being lady of the manor' [Fig.1].

Figure 1. 'We Get to Live in Mansions for Free - So Can you!', Look, $21^{\text {st }}$ June 2010, pp. 56-7.

In this, as in other 'advertorials' and favourable media articles, PG is presented as a way to 'get a leg up onto the housing ladder'"43, where eventually (with hard work) every individual, couple, or family unit can achieve the goal of home-ownership. ${ }^{44}$ These pieces have tended to frame guardianship as a temporary stepping-stone on the path to home-ownership, with PG companies actively selecting interviewees among their guardians according to profiles such as 'young successful people under the age of 25 who are looking to buy, or have recently bought a new home ${ }^{45}$. The idea of precarious tenures as a stepping-stone towards the main tenure of home-ownership is, of course, not limited to property guardianship. The discourse is deeply inscribed in housing culture in the UK and its policy-making, as manifest in old and new 'Right-tobuy' in social housing and the continuation and expansion of other mortgage incentives such as 'Help-to-buy' and 'Shared Ownership'. ${ }^{46}$ Based on our interviews, it appeared 
that any money saved by guardians for housing purposes was more likely to go towards raising a deposit in the private rented sector, rather than a mortgage on a home.

It is also worth noting that since guardians are discouraged and sometimes forbidden by their license agreement to talk to the media about the property they are in, testimonies by guardians in the mainstream media are usually carefully selected by the companies in order to give a favourable impression of the scheme to national and local media outlets. The guardians featured in the press tend to be on the younger end of the age spectrum (according to our study) and are sometimes dressed unconventionally, reinforcing ageist and cultural stereotypes of mobile and 'creative' urban dwellers. The notable absences are those with visually-identifiable mobility impairments, elderly people and those in poor health, and children. While the latter are officially not allowed on a property guardianship license, the former are implicitly excluded by the insecure and at times insalubrious living conditions in often non-residential buildings, a demonstration of an ableist normative imaginary of adventurous living and of mobility itself. $^{47}$

\section{Exceptional architectures and creative identities}

In addition, the buildings featured in most of these reports, often of historic interest and with appealing exteriors, are also cherry-picked from a much wider portfolio of properties that often includes substandard or unsuitable accommodation. It is, however, undeniable that for the guardians living in them, exceptional building typologies play a very important positive role in their rationales and narratives. For Paul, who shared a disused heritage library building with seven other guardians, the space was key, even if it was not always inhabitable: 
We had a twenty-five-metre-long living room, and we had two huge spaces, because I wanted a design studio and I just wasn't going to get that for the budget, and so we had all the space we could possibly want there, but there was no heating. And we moved in in September, I think it was, and literally we had two months that we could use it and then suddenly we were confined to our little bedrooms because we only had heating in our bedrooms and this place was just huge. $[\ldots][$ but] I loved the space.

Paul's identification with his professional practice was important to his appreciation of the building, as he explained that 'because I'm an architect, I like living in unusual places' and moving into a 'box room' would have been 'stifling', although he later admitted that in practice his actual living space in the property was also a 'box room'. While Paul's explanation draws on his professional identity, the exceptionalism inherent in his response underplays the increasing numbers of workers, beyond the 'creative' sectors, who experience a blurring of the distinction between living and working spaces. In 2014, homeworkers accounted for over $13 \%$ of the workforce in the $\mathrm{UK}^{48}$, an increase of over $20 \%$ since 2001 ; this transformation is increasingly transforming building typologies towards live/work spaces or 'workhomes'. 49

Narratives building on personal exceptionalism were not limited to first-time guardians, but were also a recurrent theme in the narratives of interviewees who had been guardians for several years. For Piero, a musician and long-term guardian, the possibility of living in non-residential buildings was central to his expectations when applying to a PG company: 
[A]s a guardian you expect to go to places that are quite stimulating, you know. I mean, for me a normal house, as beautiful as it can be, but in my mind, I don't know, it's a bit... sterile. Because you just have everything you would expect from a house, right? While living as a guardian you always know that you are gonna end up in a place that is going to be somehow, er, quirky. There is going to be something weird about it. And that's gonna be really interesting.

His experience as a guardian in Greater London led him to live in town halls, youth facilities, a former hospital and a drug rehabilitation centre. For many of the guardians interviewed, the appeal was not simply having large spaces, but also being able to share them communally: gardens, terraces, basements, former swimming pools turned into living rooms were all described and shown during the course of on-site interviews as important to living communally, as guardians praised being able to share and shape the space among groups of adults in ways that would be impossible in a flat.

\section{Moulding spaces}

In the sharing and shaping of the living spaces, guardians often gave significance to the cleaning and decorating taking place upon entering a new building and to the possibility of directly transforming the place to suit individual and collective needs. As explained by visual artist Emma, the non-residential building typology and the higher degree of dweller control, if compared to privately rented accommodation, can be a liberating experience:

I find the spaces that Camelot can offer are more mouldable. I can mould them to me. There's a certain creativity that is allowed through them, which I know very well that we would not be allowed through estate agencies. My 
environment is really important and I kind of mould that as much as when I am making my work. And so when they came along and I had this opportunity to live in a place and do what I wanted to it without any kind of response... And also having spaces which aren't structured, they are not living spaces, and you can make them into whatever you want. It offered such a kind of... liberation, I guess.

The 'moulding' of the PG spaces involves a range of activities that are usually not allowed to private tenants, such as stripping wallpaper and carpets, tiling and painting walls and floors, building shelving and other furniture. For some, such as Emma, it is part and parcel of an artistic and professional calling. Lucy became a guardian after graduating in a smaller British city and moving to London. For her, refurbishing the property was a new and exciting experience: 'we moved into a very empty, very dirty flat and got to do all the furnishing [...] we borrowed hoovers, we painted the floors'. Most of the furniture was found through web platforms such as Freecycle and through word of mouth. While the reason for refurbishment was primarily one of need, the overall narrative is a positive one of adaptability, expediency and resourcefulness to transforming a place of dwelling.

Early representations of property guardianship drew on these ideas to present it as a lifestyle choice, with Ad Hoc promoting 'guardian living' as requiring 'an adventurous attitude'. Accompanying photographs often showed young people in large rooms furnished with unconventional objects or in front of striking facades of listed buildings. On Camelot's website guardians were described as 'flexible', 'enthusiastic', possessing 'an adventurous spirit'. Many articles, often almost-exact reprints of PG companies' press releases, presented the guardian lifestyle as positive, citing the 'win- 
win' of keeping empty buildings secure and housing people in need of low-cost housing, whilst also briefly mentioning the lack of tenancy rights. ${ }^{50}$ Smaller companies established after 2009 tend to be more candid about the arrangement; on the website of Newbould Guardians, for instance, appeared the disclaimer: 'We are not estate agents! We provide ultra-low cost accommodation in central areas for people who are prepared to accept responsibilities in return, ${ }^{51}$. The imaginary ideal guardian thus appears as another version of Flint's 'responsible tenant' exercising self-governing behaviour ${ }^{52}$, while also promoting a specific approach to temporary urban living as an out of the ordinary choice that demands an adventurous and adaptable approach to place.

Promoting an adaptable approach at a time of increased stigmatisation and partial criminalisation of squatting ${ }^{53}$, PG companies can thus be seen to appropriate countercultural lifestyles and imaginaries at the same time as they push the cultural and legal boundaries of what is acceptable as 'temporary living'. Beyond a place for precarious living, PG could be seen to provide a 'squatting' experience (at a cost), which belongs to wider shifts towards depoliticised but highly aestheticized forms of 'lifestyle squatting'. ${ }^{54}$ The shift concerns material conditions as much as cultural habits: as Priemus comments, 'yesterday's squatter is today's anti-squatter' ${ }^{\text {'55; }}$ a statement that appears valid simultaneously on a symbolical and a practical level. As former guardian Elliott critically reflects, PG companies 'keep squatters out, but they essentially want you to be able to cope like a resourceful squatter'.

An interesting and perhaps unanticipated dimension of the ability to cope like a 'resourceful squatter' is visible when multiple occupancy through PG can turn into experiences of genuinely collective living. In an interesting counterpoint to the individualised imaginary of the guardian moulding their personal space, in some instances the shaping of the guardianship building occurred through collective 
assemblies and forms of self-management, which sometimes even spilled out beyond the building itself. This was the case of Assembly SE8, a collective of property guardians living in a publicly-owned school building in South London, who decided to clean and re-open the school's botanical and wildlife garden as a 'precarious public space ${ }^{56}$. Over a three-and-a-half-year period they held a range of community-oriented activities and became involved in a campaign to save the garden and challenge the lack of affordable housing in the planned redevelopment of the site. While relatively unique, the case shows how even a highly governmental form of self-precarization can be transformed, through organising, into a practice of collective self-governance and reclaiming of urban spaces for wider collective and open use.

\section{Developing an 'instinct'}

The association of specific properties with professional 'creative' identities, and the need for a 'DIY' attitude towards the space both point towards a specific 'profile' of guardians, but also to a potentially transformative experience for individuals becoming guardians and being confronted, for the first time, with forms of dweller control. As reflected by Piero, living as a guardian develops a specifically spatial 'instinct':

Everybody develops this sort of instinct, when you go into a property you scan it... and you see every opportunity in terms of like, objects, stuff that you may use, and space, you become really aware of space, you know. You become really aware of things that need to be done straight away. You become really active, somehow. Very reactive to space, and how to arrange things. It's great... it's good.... it develops a lot your survival techniques I think. 
The process of adapting and habituating oneself to property guardianship as a mode of inhabiting the city and relating to space is here framed in visceral and embodied terms as the development of instincts and survival techniques. Embracing urban selfprecarization becomes a transformative process akin to learning strategies for living in wild or highly hostile environments. The process is often narrated as a subjective shift in which the demand for flexibility from the companies is translated into positive narratives of becoming 'lighter' and 'on the move'. For long-term guardian Liam,

You're submitting yourself to a scheme where you know that you don't [have security] and it streamlines your thought processes and makes you aware... you're not, there's no pretence that this isn't a temporary situation that could end at any point.

In some cases, living as a property guardian for years means having to engage in a process of learning to make do with fewer material possessions: 'as a guardian you have to take into account that you're going be a little bit like a snail. You are going to always bring your house on your back' (Piero). For Paul, 'when you live this kind of lifestyle for a while, then it's probably for years, you make sure you have less stuff, so you know that one day you can move your stuff quickly and get quicker [at it]'. Through narratives of flexibility and adaptability to circumstances, the process of self-precarization is described as both a lifestyle and a near-ascetic attitude to material possessions and space. Such narratives strongly evoke the metaphorical figure of the nomad as 'developed to imagine the mentality of movement, a mobile habitus' moved by a desire to be 'at home everywhere' ${ }^{57}$. The shift is also indicative of a transformed embodied 
relation to the city: speed, instinctive reactions, the shedding of material objects or their metaphorical accretion into a snail shell.

Significantly, the explicit resignation toward precarization is heralded by some of the guardians we interviewed as a virtuous acquired ability that makes them more adaptable to rapid spatial and economic changes. As explained by another long-term guardian, mixed emotions accompany the development of this precarious spatial habitus':

At the beginning it is quite beautiful, you know, you are in a great building, but then after a few months there is this thing where you are made aware that actually, this is not your home. You are just occupying it on a temporary basis because the building actually has another... destination [...] it's not going to be your home. And that's a shame. But, you know, you get used to it. You get used to being precarious, you know.

The process of habituating oneself to precarity, essential to the logic of selfprecarization, can be understood as paradigmatic of the concept of 'nomadic selves' defined by cultural theorist Miwon Kwon as 'a reprisal of the ideology of 'freedom of choice' - the choice to forget, the choice to reinvent, the choice to fictionalize, the choice to 'belong' anywhere, everywhere, and nowhere' ${ }^{58}$. This is a choice that, as discussed earlier, does not belong to everyone equally. In this sense, PG symbolically and materially reproduces a normative understanding of adventure and free urban living for young, healthy, able-bodied, childless individuals. Most guardians interviewed acknowledged this, leading in some cases to a sense of discomfort at their cultural and social homogeneity, while in others to the reaffirmation of a narrative of exceptionality, 
with guardians self-defining as 'a special kind of people' ${ }^{59}$. It is worth noting here that even among those who 'choose self-precarization', stress and anxiety can be a significant barrier. As explained by Emma, who had lived with over forty guardians in multiple properties over several years, 'so many people drop out, they just have a certain tolerance point, where it's like, I can't take any more of this shit, and then they leave'. With increased awareness of the scheme and its drawbacks, over the last five years narratives of personal exceptionality and endurance have been paralleled by a growing critical discourse on guardianship and its implications, as explored below.

\section{From bohemian exceptionality to widespread precarization}

After years of positive media coverage in the UK, the kinds of critical reflections analysed above have finally percolated into mainstream public representations of the scheme. Between 2012 and 2016, representations of guardianship have gone from local media expressing somewhat naïve curiosity and often wholesale reprints of PG company press releases to more critical and investigative national and international media interest. Since summer 2015, coverage has been particularly critical, highlighting negative experiences and limitations, especially the precarious nature of this form of dwelling and the rising cost of the license fees, in some cases reaching even above market rent. Unsurprisingly, many critical articles centred on London. ${ }^{60}$ While property guardians may experience the capital's housing crisis to differing degrees of acuteness, they are likely to belong to a large portion of the capital's dwellers who are inadequately housed, and for whom tenure insecurity, particularly in the private rented sector, is growing. ${ }^{61}$

A range of media platforms, such as the generally left-wing and sensationalist Vice site, started covering PG from a more guardian-centred angle, interviewing and 
even staying with guardians. Many articles were written by early-career and even student journalists, often with a personal experience of PG and of precarious renting and working in London, exposing an increasingly personal stance on the housing crisis, with one journalist indicating the gravity of the situation by stating 'I can't even afford to be a property guardian ${ }^{, 62}$. The systemic critique encompassed the residualisation of social housing, the increased promotion of right-to-buy and its extension into the social housing sector, and the apparent inability of local and central governments to display initiative, particularly in relation to tenure insecurity with $\mathrm{PG} .{ }^{63}$ By 2015 , when The Guardian newspaper asked whether PG was 'the solution to the housing crisis', the answer was an extensive critical analysis and a resounding 'no' from guardians and the researchers quoted. ${ }^{64}$

Moving from the printed press to television fiction, in early 2016 a six-part comedy series on Channel $4 \mathrm{TV}$, Crashing, documented the highs and lows of six people living as guardians in a hospital building in London. The quest to find out about 'the real Crashing' spurred a number of journalists to seek out guardians to tell their stories during the six weeks of transmission. ${ }^{65}$ The coverage, focusing more on guardians' experiences and less on press releases and companies' briefings, was largely negative, including in unlikely arenas such as the right-wing Daily Mail. ${ }^{66}$ Guardians were presented on the $\mathrm{BBC}$ website not as the solution, or the lucky few, but as 'the hidden faces of the housing crisis', in a photo-series hosted to coincide with the BBC Three TV series Hidden and Homeless. ${ }^{67}$ A more unfettered and nuanced mass media approach to PG may reflect a growing understanding and organizing around housing issues, especially in London and the South-East of England.

The emergence of situated investigative journalism into guardianship in the context of unaffordable housing provision, can be seen to mark a discursive shift from 
bohemian exceptionality to an awareness of widespread precarization. Guardians interviewed in 2014-15 increasingly compared guardianship to other forms of housing provision. As explained by Anne,

of all the renting experiences I've had in London, yes Camelot was stressful because you never knew when they were going to turn on you but, actually, out of the places I've lived in London, that's the place I stayed at longest, and in terms of location and value for money, it was probably the best!

Attitudes such as this are indicative of a wider awareness of housing conditions among guardians as well as among the wider public. Guardians' comparison of PG with the private rented sector (PRS) clearly shows that their self-precarization is not understood as a 'security' aberration, but as a marker of a much wider housing crisis, and of a regime of normalized urban precarity particularly for young adults for whom insecure private renting is the only available option. ${ }^{68}$ Challenging narratives of exceptionality, flexibility and endurance, guardianship becomes a lens through which generations of young graduates understand the unsustainability of the highly insecure PRS ${ }^{69}$, particularly in London. In this context, guardians' self-precarization is part lifestyle choice and part survival strategy: a profoundly ambivalent approach to a polyvalent form of urban dwelling marked simultaneously by resignation and by a sense of virtuous adaptability to changed conditions.

In the wider UK context, mainstream discourse and policy-making still propose homeownership for an individual or a family unit as the solution to the housing crisis. In this context, the pervasive idea of different precarious tenures, such as property guardianship, as 'stepping stones' towards owning a home is at once seductively 
teleological and profoundly depoliticising, since the transformation of existing insecure conditions is permanently deferred. Moreover, this individualised representation of the housing crisis and its solutions negates the ways in which the crisis of affordability has already given rise to forms of collective living, from adult multiple occupancy homes to more problematic forms of overcrowding. ${ }^{70}$ In this context, not only PG schemes are not a solution to the housing crisis, but they are a part of the problem, both materially, as free or low-cost security of building whose future use might involve speculation, privatisation and redevelopment, and affectively, in terms of generating widespread resignation and ambivalence to precarization.

\section{Conclusions}

Practices of precarious dwelling through property guardianship are reshaping representations of desirable urban living by pushing the boundaries of what is acceptable as well as the forms of addressing and dealing with new conditions of housing insecurity. What has clearly emerged in our analysis is that the mobilisation of notions of flexibility and adventurousness belongs to a neoliberal discourse of individual adaptability to conditions of normalised precarization; the 'nomadic' selves and values of representation and self-representation remain problematic at a time when such values appear 'to be closer to hegemonic constructs than ideals of resistance'. ${ }^{71}$ Nonetheless, deploying a critical cultural approach to self-precarisation through PG is important to tease out some of the emancipatory desires inherent in many of our interviews and captured in guardianship companies' self-promotion. Attributes of autonomous living within the PG imaginary can offer insights into the workings of neoliberal urban subjectification through self-precarization but also into desires for 
different modes of living and relating to urban space that are, in practice, increasingly foreclosed in cities ruled by real estate speculation and geared towards its upkeep through, in this case, new sophisticated forms of securing private property. This has both theoretical and political implications for understanding emerging cultures of precarious geographies.

Theoretically, it requires addressing new precarious living arrangements, such as PG, as existing at the polyvalent interplay of narratives of adaptability, adventurousness and exceptionality, and less glamorous lived experiences. Firstly, in contrast to the deterritorialised idea of hyper-mobile nomadism and detachment critically associated with imaginaries of flexible nomadic spaces, such as Archizoom's 'No-Stop City', beyond economic advantage, the rationale offered by guardians points to a desire for unconventional and 'mouldable' spaces; spaces that can be physically transformed through inhabitation. This 'mouldable' possibility reasserts, in the guardians' narratives and rationales, a desire for appropriation and transformation of living spaces based on the use of its inhabitants, in other words dweller control, something which is often denied through conventional PRS tenancy agreements and which seems only possible through financially unreachable home-ownership. Living in unusual non-residential buildings may offer the 'bare infrastructure' that utopian architects have long posited as fundamental to allowing inhabitants to 'reshape their environments according to their needs and desires ${ }^{72}$. With our analysis of PG we have therefore contributed to cultural geography literature on temporariness, nomadism and flexibility in urban imaginaries by exploring how these inform contemporary lived experiences and dwelling practices.

Secondly, by proposing to take self-precarization as a theoretical frame for thinking about emerging cultures of urban precarity, we have argued for the need to 
understand the construction of a precarious urban habitus not only as a condition of subjection but also as informed by and generative of embodied critiques of mainstream urban conditions. While the method of individual in-depth interviews may reinforce the idea of individualised trajectories, site visits and instances in the guardians' narratives have highlighted a significant desire for forms of communal living, so that we may talk of collective $d$ wellers' control. Furthermore, even if a uniquely developed example in the context of London, the experience of Assemble SE8 has shown that the desire for collectivising vacant spaces through use can expand beyond the building into attempts to shape public spaces and planning policy, moving from individual mouldable spaces to communal and wider neighbourhood transformation. Thirdly, by paying close attention to the normativity and exclusivity of imaginaries and practices of selfprecarization such as property guardianship, in this article we have engaged with and contributed to critical literature on flexibility and mobilities as a fundamental corrective to the ideology of the freedom of choice, and its specific relation to contemporary housing conditions.

Finally, we have argued that guardians' desire for autonomous and collective dwelling has important political implications for addressing the emerging habituation to precarious urban living. At this political conjuncture, the shift from imaginaries of bohemian exceptionality towards an increasingly critical look at guardianship in the context of housing precarization could offer the grounds for collective organising, as has been recently illustrated by the 'Camesquat' occupation ${ }^{73}$ and by a court case concerning insalubrious conditions in a PG building in Bristol. ${ }^{74}$ Beyond demands for improved conditions and the possibility of inscribing guardianship as a tenure within housing law, reflexive guardianship practice is moving towards a critique of the widespread conditions that lead to the emergence of such schemes, and importantly, to 
their desirability. Such a wider critique could be shared with wider movements for communal and self-organised housing such as the short-life cooperative movement and other, more politicised forms of 'licensed squatting, ${ }^{75}$, as well as more permanent forms of co-housing, intentional communities and cooperatives. At a moment of extensive governmentality through insecurity, a nuanced understanding of the cultural imaginaries mobilised by emerging forms of collective precarious dwelling can shed light on new meanings and subjectivities articulated from and through largely ambivalent lived experiences. Without facile celebrations, imaginaries and practices of self-precarization can offer a critical starting point for understanding and rethinking, both theoretically and politically, housing precarity and its geographies.

Acknowledgments: We would like to thank all our research participants for their time, and the editors and anonymous reviewers for their insightful comments. Special thanks go to Alex Vasudevan for his ongoing theoretical engagement during this collective research project. Any flaws or inaccuracies in the argument are entirely ours. Part of the writing of this paper has been supported by funding from the European Union's Horizon 2020 research and innovation programme under the Marie Skłodowska-Curie grant agreement No 665919 
${ }^{1}$ Interview with property guardian Emma, London, $20^{\text {th }}$ November 2011.

${ }^{2}$ Orbis, White Paper on Property Guardianship, (2014) [online] http://www.orbisprotect.com [accessed $27^{\text {th }}$ June 2014].

${ }^{3}$ See M. Ferreri, G. Dawson and A. Vasudevan, Living precariously: property guardianship and the flexible city. Transactions of the Institute of British Geographers, 42 (2017), pp. 246-259.

${ }^{4}$ C. Clemoes, Property Guardians, London: The State of Housing in Transient Places (UCL, Unpublished MSc Urban Studies thesis, 2013-14). See also Property Guardian Research Collective, The Temporary Home: Live-in Guardians in the Neoliberal City, New Left Project (2014) [online] http://www.newleftproject.org/index.php/site/article_comments/the_temporary_home _live_in_guardians_in_the_neoliberal_city [accessed $12^{\text {th }}$ October 2015].

${ }^{5}$ G. Peaker, Quis custodiet ipsos custodes?, Nearly Legal Blog (22 November 2012) [online] http://nearlylegal.co.uk/2012/11/quis-custodiet-ipsos-custodes/ [accessed $22^{\text {nd }}$ September 2014].

${ }^{6}$ See O. Wainwright, Live in a stately home - just don't get too settled in, The Guardian, 22 ${ }^{\text {nd }}$ July 2013.

${ }^{7}$ M. Hyland, Embedded Adventurism, Mute Magazine (2007) [online] at http://www.metamute.org/editorial/articles/embedded-adventurism [accessed $2^{\text {nd }}$ March 2016].

${ }^{8}$ D. Pinder, Cities moving, plugging in, floating, dissolving, in Cresswell and Merriman, Geographies of Mobilities, pp. 167-188.

${ }^{9} \mathrm{~T}$. Sutherland, Intensive mobilities: figurations of the nomad in contemporary theory, Environment and Planning D: Society and Space, 32(5) (2014), pp. 935-50.

${ }^{10}$ T. Cresswell and P. Merriman (eds), Geographies of Mobilities: Practices, Spaces, Subjects, (London, Routledge, 2011).

${ }^{11}$ C. Hunter and G. Peaker, Who guards the guardians?, Journal of Housing Law, 297, Vol. XVI (2012).

${ }^{12}$ L. Owens, Cracking Under Pressure: Narrating the Decline of the Amsterdam Squatters' Movement (Amsterdam, Amsterdam University Press, 2009), p. 204.

${ }^{13}$ Op. cit.

${ }^{14}$ J. Uitermark, An actually existing just city? The fight for the right to the city in Amsterdam. In Brenner, N., P. Marcuse and M. Mayer (eds), Cities for People, Not for Profit: Theory/Practice (Oxford, Routledge, 2011), pp. 197-214.

${ }^{15}$ Op. cit. 
${ }^{16} \mathrm{H}$. Priemus, Squatters and municipal policies to reduce vacancy. Evidence from The Netherlands, ENHR Conference 2011 [online] http://www.enhr2011.com/sites/default/files/Paper-H.Priemus-WS21.pdf, ., p. 3.

${ }^{17}$ Exaggerated accounts of the number of squatted properties in England and Wales are regularly used by PG companies in promotional online videos and security sector 'vacant property' workshop aimed at property owners and managers, which authors attended in 2010 and 2013.

${ }^{18}$ L. Finchett-Maddock, Protest, property and the commons: performances of law and resistance (London and New York, Routledge, 2016), p. 60.

${ }^{19}$ A. Vasudevan, The Makeshift City: towards a global geography of squatting, Progress in Human Geography, Issue 39 (2015), pp. 338-359.

${ }^{20}$ H. Lewis, P. Dwyer, S. Hodkinson and L. Waite, Hyper-precarious lives: migrants, work and forced labour in the Global North, Progress in Human Geography, Issue 39 (2015), pp. 580-600; L. Waite, A Place and Space for a Critical Geography of Precarity?, Geography Compass, Issue 3 (2009), pp. 412-433; S. Banki, Precarity of place: a complement to the growing precariat literature, Global Discourse, Issue 3 (2013), pp. 450-463.

${ }^{21}$ Gill and Pratt, Social Factory.

${ }^{22}$ B. Neilson and N. Rossiter, From precarity to precariousness and back again: labour, life and unstable networks, The Fibreculture Journal, issue 5 (2005) [online] five.fibreculturejournal.org/fcj-022-from-precarity-to-precariousness-and-back-againlabour-life-and-unstable-networks/ [accessed $12^{\text {th }}$ April 2013].

${ }^{23}$ Vasudevan, The Makeshift City.

24 J. Butler, Precarious Life: The Powers of Mourning and Violence (London, Verso, 2006); J. Butler, Foreword, in Isabell Lorey, State of Insecurity: Government of the Precarious (London, Verso, 2015), pp. vii-xi.

${ }^{25}$ I. Lorey, State of Insecurity: Government of the Precarious (London, Verso, 2015).

${ }^{26}$ I. Lorey, Governmentality and Self-Precarization. On the normalization of cultural producers (Trans. D. Fink and L. Rosenblatt), transversal (2006) [online] http://eipcp.net/transversal/1106/lorey/en [accessed $13^{\text {th }}$ June 2015]

${ }^{27}$ Lorey, State of Insecurity, p. 1.

${ }^{28}$ Lorey, Governmentality.

${ }^{29}$ Op. cit.

${ }^{30}$ Lorey, State of Insecurity, p.14. 
${ }^{31}$ Op. cit.

${ }^{32}$ B. Holmes, The Flexible Personality: For a New Cultural Critique, Transversal (2012) [online] http://eipcp.net/transversal/1106/holmes/en [accessed $13^{\text {th }}$ February 2012].

${ }^{33}$ L. Boltanski and E. Chiapello (Trans. Gregory Elliott) The New Spirit of Capitalism (London, Verso, 2005).

${ }^{34}$ See D. Pinder, Utopian transfiguration: the other spaces of New Babylon, in Borden, I. and S. Mccreery (eds), 'New Babylonians', Architectural Design, 71(3) (2001), pp. 15-19.

${ }^{35}$ D. Murphy, Last Futures. Nature, Technology and the End of Architecture (London, Verso, 2016), p. 150.

${ }^{36}$ Op. cit.

${ }^{37}$ Intensive periods of research in June-July 2012, January-February 2015 and Sept 2015-March 2016 involved reviews of online publication of mainstream as well as alternative national and local news platforms, and architecture and activist blogs.

${ }^{38}$ Clemoes, Property Guardians.

${ }^{39}$ A. McRobbie, Making a Living in London's Small Scale Creative Sector. In Power, D. and Scott, A. J. (eds) Cultural Industries and the Production of Culture (London, Routledge, 2004), pp. 130-142.

${ }^{40}$ R. Gill and A. Pratt, In the social factory?: Immaterial labour, precariousness and cultural work, Theory, Culture and Society, Issue 25 (2008), pp. 1-30.

${ }^{41}$ For a more in-depth discussion of the project's methodology, see Ferreri et al., Living precariously.

${ }^{42}$ K. Brickell, 'Mapping'and 'doing' critical geographies of home, Progress in Human Geography, Issue 36(2) (2012), p. 227.

${ }^{43}$ N. Hodgson (2015), Guardian Angels helping to solve property problems, Liverpool Echo, 3 September 2015 [online] http://www.liverpoolecho.co.uk/news/business/guardian-angels-helping-solveproperty-9976362 [accessed 22 October 2015].

${ }^{44}$ C. Allen, Housing Market Renewal and Social Class (Abingdon, Routledge, 2008).

${ }^{45}$ Verbatim from a group email by a PG company addressed to guardians regarding the filming of a television documentary, seen by author (November 2010).

${ }^{46}$ S. Hodkinson, P. Watt and G. Mooney, Neoliberal Housing Policy - Time for A Critical re-Appraisal, Critical Social Policy 33(1) (2013), pp. 3-16. 
${ }^{47}$ T. Cresswell, Towards a politics of mobility, Environment and planning D: society and space, 28, (1) (2010), pp. 17-31.

${ }^{48}$ Office for National Statistics, Characteristics of Home Workers (2014), 4 June 2014.

${ }^{49}$ F. Holliss, Space, Buildings and the Life Worlds of Home-Based Workers:

Towards Better Design. Sociological Research Online 17 (2) (2012); see also F. Holliss, Beyond Live/Work: The Architecture of Home-based Work (London and New York, Routledge, 2015).

${ }^{50}$ A. Binnie, Rickmansworth's old police station is now being lived in, Watford Observer, $7^{\text {th }}$ June 2012 [online],

www.watfordobserver.co.uk/news/9749466.Old_police_station_is_home_sweet_ho me/ [accessed 12 ${ }^{\text {th }}$ August 2012].

${ }^{51}$ Newbould Guardians website [online] www.newbouldguardians.co.uk/guardianfaqs/ [accessed 23 ${ }^{\text {rd }}$ June 2016].

52 J. Flint, The responsible tenant: housing governance and the politics of behavior, Housing Studies, 19(6) (2004), pp. 893-909.

${ }^{53}$ We are here referring to the 'Legal Aid, Sentencing and Punishment of Offenders Act 2012'.

${ }^{54}$ Hyland, Embedded Adventurism.

${ }^{55}$ Priemus, Squatters, p. 3.

${ }^{56}$ See Old Tidemill Garden [online] http://gardenlab.org.uk/about/ and http://oldtidemillgarden.wixsite.com/deptford/about-the-garden [accessed $23^{\text {rd }}$ April 2017].

${ }^{57}$ A. I. Engebrigtsen, Key figure of mobility: the nomad, Social Anthropology 25(1) (2017), p. 45.

${ }^{58}$ M. Kwon, One Place After Another: Site-Specific Art and Locational Identity, (Cambridge MA, MIT Press, 2004), p. 165.

${ }^{59}$ C. Clemoes, Guardian property: freedom at another's expense, Failed architecture (2015)[online] http://www.failedarchitecture.com/guardian-property-freedomexpense/ [accessed $10^{\text {th }}$ September 2015].

${ }^{60}$ M. Oppenheim, 'I Can't Even Afford to be a Property Guardian', New Statesman, $27^{\text {th }}$ July 2016 [online] http://www.newstatesman.com/politics/2015/07/i-cant-evenafford-be-property-guardian [accessed $2^{\text {nd }}$ March 2016]; Gharsali, S., Property Guardians: The plight of cheap rent, Artefact magazine, n.d. [online] https://www.artefactmagazine.com/2016/03/18/property-guardians-the-plight-ofcheap-rent/ [accessed $2^{\text {nd }}$ March 2016]. 
${ }^{61}$ P. Watt and A. Minton, London's housing crisis and its activisms, City, 20(2) (2016), pp. 204-21.

62 Oppenheim, I Can’t Even Afford to be a Property Guardian.

${ }^{63}$ L. Amin and M. Gibbs, The high price of cheap living; how the Property Guardianship dream soured, The Guardian online, $24^{\text {th }}$ December 2015 [accessed $13^{\text {th }}$ June 2015].

${ }^{64}$ C. England, Property Guardians: a solution to the UK's housing crisis?, The Guardian sustainability blog, $24^{\text {th }}$ March 2015 [online] http://www.theguardian.com/sustainable-business/2015/mar/24/property-guardianshousing-solution-opportunism_[accessed $2^{\text {nd }}$ March 2016].

65 T. Zephyr, My real-life experience as a property guardian was anything but funny, The Guardian [online] http://www.theguardian.com/housingnetwork/2016/jan/18/property-guardian-channel-4-crashing-generation-rent_[accessed $2^{\text {nd }}$ March 2016].

${ }^{66} \mathrm{M}$. Davidson, Being a property guardian means you can rent rooms in interesting buildings for half the going rate, Daily Mail, 13 ${ }^{\text {th }}$ January 2015.

${ }^{67}$ S. Wedgewood, The Hidden Faces of The Housing Crisis, BBC Three, n.d, http://www.bbc.co.uk/bbcthree/item/2b0453a7-d353-4b80-828d-50274799d5c6 [accessed $2^{\text {nd }}$ March 2016]

${ }^{68}$ Bone, J., Neoliberal Nomads: Housing Insecurity and the Revival of Private Renting in the UK, Sociological Research Online, 19 (4) (2014).

${ }^{69} \mathrm{P}$. A. Kemp, Low-income tenants in the private rental housing market, Housing Studies 26 (2011), pp. 1019-1034.

${ }^{70}$ Watt and Minton, London's housing crisis.

${ }^{71}$ Sutherland, Intensive Mobilities.

${ }^{72}$ D. Pinder, Visions of the City. Utopianism, Power and Politics in TwentiethCentury Urbanism (Edinburgh, Edinburgh University Press, 2005), p. 200.

${ }^{73}$ See M. Ferreri, G. Dawson and A. Vasudevan, Property guardians: when private security becomes precarious housing, Geography Directions blog (2016) [online] https://blog.geographydirections.com/tag/precarious-geographies/ [accessed $12^{\text {th }}$ May 2017].

${ }^{74}$ See D. Hooper, Residents in Bristol accuse management firm of neglect, 11 January 2017, BBC News Bristol http://www.bbc.com/news/uk-england-bristol-38571963 [accessed $2^{\text {nd }}$ February 2017].

${ }^{75}$ C. Wiles, In a guardian time, Inside Housing, Issue 5 (September 2015) [online]. 
